MS. PAULA SANGINÉS DE CÁRCER (Orcid ID : 0000-0003-1238-2491)

DR. YANN VITASSE (Orcid ID : 0000-0002-7454-505X)

DR. VINCENT E.J. JASSEY (Orcid ID : 0000-0002-1450-2437)

DR. CONSTANT SIGNARBIEUX (Orcid ID : 0000-0001-7780-5366)

Article type : Primary Research Articles

\title{
Vapor-pressure deficit and extreme climatic variables limit tree growth
}

Running head: Vapor-pressure deficit limits tree growth

Sanginés de Cárcer, P. ${ }^{1,2^{*}}$, Vitasse, $\mathrm{Y}^{3,4}$, Peñuelas, J. ${ }^{5}$, Jassey, V.E.J. ${ }^{1,2,6}$, Buttler, A. ${ }^{1,2,7}$, Signarbieux, C. ${ }^{1,2}$

1 École Polytechnique Fédérale de Lausanne EPFL, School of Architecture, Civil and Environmental Engineering ENAC, Laboratory of Ecological Systems ECOS, Station 2, 1015 Lausanne, Switzerland

${ }^{2}$ Swiss Federal Institute for Forest, Snow and Landscape Research WSL, Site Lausanne, Station 2, 1015 Lausanne, Switzerland

${ }^{3}$ Swiss Federal Institute for Forest, Snow and Landscape Research WSL, Neuchatel, Switzerland.

${ }^{4}$ University of Neuchatel, Institute of Geography, Neuchâtel, Switzerland

5 CREAF-CSIC, Global Ecology, Facultat Ciències Universitat Autonoma Barcelona, 08193, Bellaterra, Catalonia, Spain

${ }^{6}$ Université de Toulouse, INP, UPS, CNRS, Laboratoire d'Ecologie Fonctionnelle et Environnement (Ecolab), 118 Route de Narbonne, 31062 Toulouse Cedex, France

${ }^{7}$ Laboratoire de Chrono-Environnement, UMR CNRS 6249, UFR des Sciences et Techniques, 16 route de Gray, Université de Franche-Comté, F-25030 Besançon, France

Corresponding author *: Paula Sanginés de Cárcer+41216932402 paula.sanginesdecarcer@epfl.ch Paper type: primary research article

\begin{abstract}
Assessing the effect of global warming on forest growth requires a better understanding of species-specific responses to climate change conditions. Norway spruce and European beech are among the dominant tree species in Europe and are largely used by the timber industry.

This article has been accepted for publication and undergone full peer review but has not been through the copyediting, typesetting, pagination and proofreading process, which may lead to differences between this version and the Version of Record. Please cite this article as doi: $10.1111 / \mathrm{gcb} .13973$

This article is protected by copyright. All rights reserved.
\end{abstract}


Their sensitivity to changes in climate and extreme climatic events, however, endangers their future sustainability. Identifying the key climatic factors limiting their growth and survival is therefore crucial for assessing the responses of these two species to ongoing climate change. We studied the vulnerability of beech and spruce to warmer and drier conditions by transplanting saplings from the top to the bottom of an elevational gradient in the Jura Mountains in Switzerland. We (1) demonstrated that a longer growing season due to warming could not fully account for the positive growth responses, and the positive effect on sapling productivity was species-dependent, (2) demonstrated that the contrasting growth responses of beech and spruce were mainly due to different sensitivities to elevated vapor-pressure deficits, (3) determined the species specific limits to vapor-pressure deficit above which growth rate began to decline and (4) demonstrated that models incorporating extreme climatic events could account for the response of growth to warming better than models using only average values. These results support that the sustainability of forest trees in the coming decades will depend on how extreme climatic events will change, irrespective of the overall warming trend.

\section{Keywords}

Tree growth, spruce, beech, climate change, vapor-pressure deficit, extreme events, wooded pastures

\section{Introduction}

Climate change is currently escalating so rapidly that many trees may not be able to adapt (Rogers, Jantz, \& Goetz, 2017). In addition to the gradual global warming, the frequency and severity of extreme events such as heat waves, heavy precipitation, summer droughts and cold spells are expected to increase in the coming decades (IPCC, 2013; Schar et al., 2004), which may ultimately determine future tree distributions (Zimmermann et al., 2009). Extreme events can have strong impacts on tree growth and survival, due to typically stronger responses and shorter response times than for normal climatic events (Hanson, Palutikof, Dlugolecki, \& Giannakopoulos, 2006; Kreyling, Jentsch, \& Beierkuhnlein, 2011). Forest researchers must estimate the resilience of forests to expected climate change and extreme climatic events to guide sustainable forest management (Lindner et al., 2014). An increasing number of studies are therefore testing the impact of extreme events on forest growth (Ciais 
et al., 2005; Teskey et al., 2015), some under controlled conditions (Lendzion \& Leuschner, 2008). Experiments are often conducted ex situ (e.g. in climate-controlled chambers), which is valuable for understanding the impact of a single factor on tree physiology but does not represent real in situ conditions that involve many abiotic and biotic interactions that determine tree growth (De Boeck, Dreesen, Janssens, \& Nijs, 2010; Körner et al., 2016; Vicca et al., 2016; Zimmermann et al., 2009).

Increased tree growth has been correlated with warmer temperatures (Way \& Oren, 2010) and longer growing seasons (Keenan, 2015; Menzel \& Fabian, 1999; Piao, Friedlingstein, Ciais, Viovy, \& Demarty, 2007; Signarbieux et al., 2017). However, divergent responses to warming among co-existing tree species have been also widely reported (C. Allen et al., 2010; Carnicer, Barbeta, Sperlich, Coll, \& Penuelas, 2013), reflecting different physiological needs and growth strategies. A change in environmental conditions due to altitude is one of the factors leading to this divergence. For instance, tree growth during the extremely hot and dry summer in 2003 in the Swiss Alps increased at high altitudes but decreased at low altitudes (Jolly, Dobbertin, Zimmermann, \& Reichstein, 2005). This contrasting growth response was explained by the differences in resource, temperature and water limitations between lower and higher elevations.

Shifts in the onset of spring phenology, due to increasing temperatures, generally are related to an increase in growing season length (Keenan, 2015). It has been reported that leaf unfolding of European woody species has advanced by about 13 days during the period 19822011 in Europe, which together with delayed autumn phenology has contributed to extend the growing vegetative period ( $\mathrm{Fu}$ et al., 2014) by 24 days during the same period (Kolářová, Nekováŕ, \& Adamík, 2014). Moreover, it has been hypothesized that the length of the growing season affects productivity to a larger extent in angiosperms than in conifers (Carnicer et al., 2013). However, Körner (2017) argued that longer growing seasons may contribute to higher annual tree growth, but only to a certain limit, which is not yet clearly identified (Delpierre, Guillemot, Dufrêne, Cecchini, \& Nicolas, 2017).

The stomatal response of trees to changing environmental conditions is complex and it is a process which is still not well understood (Damour et al., 2010). The closure of stomata at midday is regulated by the water available in the soil, leaf and atmosphere, and it is highly species-specific (Bond \& Kavanagh, 1999). Stomatal responses to increasing evaporative demand of the air seem to be another explanation for the contrasting growth responses

This article is protected by copyright. All rights reserved. 
between functional groups. Carnicer et al. (2013) reviewed various hypotheses that could account for the contrasting responses of growth to temperature in Mediterranean angiosperm and coniferous trees. They included a hypothesis involving the effect of eco-physiological and hydraulic traits on tree growth. More specifically, they suggested that different sensitivities of stomatal conductance to vapor-pressure deficit (VPD) lead to different growth responses. Several studies have been performed in order to understand the mechanisms triggering stomatal closure in response to vapor-pressure deficit (Sellin, 2001; Brodribb \& McAdam, 2011; Mott \& Peak, 2013) and agree that stomata typically close at high VPD and open at low VPD (McAdam \& Brodribb, 2015). The sensitivity of VPD to changes in air temperature differs among plant functional groups (Ogaya \& Peñuelas, 2007; Way \& Oren, 2010) and underlies the strategies optimizing carbon uptake with reduced water loss (Franks \& Farquhar, 1999). For instance, the positive response of growth to increased temperature in angiosperms could be due to a narrower hydraulic safety margin and a higher capacity to reverse embolisms (Carnicer et al., 2013). The higher hydraulic safety margin in conifers implies an earlier response of stomatal closure before cavitation (Carnicer et al., 2013), at a cost of reducing carbon uptake. Therefore, vapor-pressure deficit (VPD) can limit tree growth (C. D. Allen, Breshears, \& McDowell, 2015), however, its importance has not been fully recognized (Lendzion \& Leuschner, 2008). Leaf-to-air VPD is expected to increase with the predicted increase in air temperature (Novick et al., 2016), with subsequent impacts on plant transpiration and photosynthesis. Reciprocal common garden experiments along altitudinal transects have been suggested to be a powerful tool for testing ecological responses to changes in environmental conditions (Carnicer et al., 2013; Körner, 2007), such as increasing temperature and evaporative demand of the air. This type of experiment is based on the variation of environmental conditions (temperature, atmospheric pressure, etc.) with elevation, simulating climate change conditions without needing to wait decades to observe an impact and therefore predict responses and adapt forest managements. Most studies of the impacts of climate change on vegetation are based on changes in the averages of climatic variables (Miyamoto, Griesbauer, \& Scott Green, 2010), such as the mean annual or summer temperature. Extreme climatic events can have a large effect on tree growth but have been rarely studied (Lendzion \& Leuschner, 2008; Teskey et al., 2015) and there is no accurate definition related to the existence of an "extreme" (Stephenson, 2008). In this study, we defined "extreme" according to IPCC (Murray \& Ebi, 2012), i.e. we quantified climate extremes by determining specific thresholds above which tree growth could be largely affected. We thus analyzed the effects of changes in climatic factors on the growth of beech 
and spruce saplings and compared the variances of the data for averages vs. extremes. Specifically, our main questions were: 1) how does species-specific growth respond to warmer and drier conditions, 2) to what extent does a longer growing season increase tree growth, 3) how does an elevated VPD affect tree growth and 4) what benefit does the study of "extreme conditions" have on a mechanistic understanding of the responses of tree growth under various environmental conditions? The novelty in this study is that we used a 'natural warming experiment' to assess how trees adapted to cold and wet environments respond to warmer and drier conditions by a translocation experiment along a transect across an elevational gradient. Generally, elevational gradient experiments compare populations of a same species but growing at different elevations, or use climate chambers to control climatic variables, without taking account the effects of extreme climatic variables. In our approach, we transplanted beech and spruce saplings from a donor site at a high elevation to three recipient sites at lower elevations to assess the effects of warmer and drier conditions on growth of individuals adapted to cold and wet environments. We focused on the saplings of the two dominant sylvopastoral species of the Jura Mountains, Norway spruce and European common beech. A good understanding of regeneration and its consequences under conditions of climate change are crucial for both species conservation and the sustainable and adaptive management of landscapes (Buttler 2014). These two species are also among the dominant trees in central Europe and are key to the timber industry, so forest managers need to know whether they will be sustainable in the coming decades.

\section{Materials and methods}

\section{Study sites and elevational gradient}

The conditions of climate change were simulated using an elevational gradient along a southfacing slope of the Jura Mountains in Switzerland. This space-for-time substitution (Körner, 2003) simulated a climatic gradient, i.e. an increase in temperature and a decrease in precipitation towards lower altitudes. A detailed description of the site selection is given by Gavazov et al. (2014). Briefly, the donor site was at Combe des Amburnex (N4654', E6 233'; $1350 \mathrm{~m}$ a.s.1.), with an oceanic climate, a mean annual temperature and precipitation of $4.5^{\circ} \mathrm{C}$ and $1750 \mathrm{~mm}$, respectively, and a permanent snow cover from November to may (K. S. Gavazov, Peringer, Buttler, Gillet, \& Spiegelberger, 2013). The three recipient sites were at St.-George at $1010 \mathrm{~m}$ a.s.1. (N46 52', E6 $\left.{ }^{\circ} 26^{\prime}\right)$, Arboretum d'Aubonne at $570 \mathrm{~m}$ a.s.l. 
(N46 $\left.51^{\prime}, \mathrm{E}^{\circ} 37^{\prime}\right)$ and Les Bois Chamblard at $395 \mathrm{~m}$ a.s.1. (N46 $\left.47^{\prime}, \mathrm{E}^{\circ} 41^{\prime}\right)$. Combe des Amburnex was the control site with native climatic conditions, so this climatic gradient covered three possible warming scenarios of the Intergovernmental Panel on Climate Change (K. S. Gavazov et al., 2013; K. Gavazov et al., 2014): moderate at $1010 \mathrm{~m}$ a.s.l. (on average + $2^{\circ} \mathrm{C}$ and $20 \%$ rainfall reduction), intermediate at $570 \mathrm{~m}$ a.s.1. $\left(+4^{\circ} \mathrm{C}\right.$ and $40 \%$ rainfall reduction) and extreme at $395 \mathrm{~m}$ a.s.1. ( $+5^{\circ} \mathrm{C}$ and $50 \%$ rainfall reduction).

In this study we mainly focused on the impact of changes in air temperature and precipitation in the tree growth of saplings. However, we acknowledge that there is a decrease in total atmospheric pressure and partial pressure of gases with altitude, as well as an increase in radiation under cloudless sky due to a decrease in atmospheric turbidity (Körner, 2007). Sanginés et al. (2017) showed that temperature gradients had a major effect on the morphological changes of leaves as compared to changes in partial pressure. Regarding solar radiation, the actual dose received by a plant will also depend on scattering elements such as clouds, which generally increase with altitude in mountain regions (Körner, 2007). Therefore, we assume that the increase in solar radiation at high elevations during the growing season is, to some extent, compensated with the associated increase in cloudiness. To support this assumption, we visually inspected the data of solar radiation recorded by meteo-stations placed at our study sites and observed similar July solar radiation averages and same trends along the spatial-temporal gradient (data not shown).

\section{Experimental design and species}

Saplings of beech (Fagus sylvatica L.) and spruce (Picea abies (L.) H.Karst.) were collected at the donor site $(1350 \mathrm{~m})$ immediately before the budburst of the 2012 growing season. The surface of collection was assumed to be reduced enough to ensure the same provenance of saplings. The saplings had similar sizes (average height of $33 \mathrm{~cm}$ for beech and $31 \mathrm{~cm}$ for spruce) and were excavated with intact root systems and soil. They were then transplanted to $20-\mathrm{L}$ pots and randomly reallocated in four plots, one at each elevation, in open spaces and far enough from the forest to avoid shade from surroundings adult trees. Half of the saplings were transplanted a second time to 40-45-L pots in autumn 2014, two years after the first transplantation, due to the potential limitation of growth by the initial pots. The other half was harvested for analysis. The soil of the harvested plants was used for the transplantation of the remaining individuals to maintain the same soil characteristics for each species and site.

This article is protected by copyright. All rights reserved. 
The experimental design was a generalized block with repeated measures (2013, 2014 and 2015). The four blocks were considered as fixed and corresponded to the four sites at altitudes of 1350, 1010, 570 and $395 \mathrm{~m}$. Ten replicate saplings per species (beech and spruce) and treatment (non-irrigated and irrigated) were randomly allocated within each block. The experimental unit was a pot with one sapling, which was randomly placed on a grid with a spacing of $0.3 \times 0.9 \mathrm{~m}$ to avoid light competition. The pots were recessed belowground, and a geotextile cap was placed at the top and bottom of the pots to reduce both the evaporation of soil water and the penetration of roots into the soil of the site. All sites were equipped with wireless meteorological stations (Sensorscope, Climaps. available at: https://www.climaps.com/) that continuously recorded climatic parameters (precipitation and air temperature), enabling us to add water weekly during the growing season to ensure equal amounts of precipitation at the recipient and donor sites for the irrigated treatment. The saplings in the non-irrigated treatment were subjected to the local environmental conditions of each site. The purpose of the irrigation treatment was to identify the effect of rainfall for studying the responses of the saplings to temperature alone.

\section{Biomass estimation}

\section{In situ measurements of growth rate}

Growth was monitored twice (before budburst and after senescence) for all saplings for three consecutive growth periods $(2013,2014$ and 2015) to evaluate the effects of the changes in environmental conditions on aboveground biomass. Overall growth was estimated by dasometric measurements of the stem and four main branches. The four longest branches for each sapling were identified and tagged to allow continuous monitoring. Stem and branch diameters (basal and apical) were measured using an electronic caliper with an accuracy of $0.01 \mathrm{~mm}$. The basal diameter $(S b)$ of the stem was an average of two perpendicular measurements approximately $1-2 \mathrm{~cm}$ from the base of the root collar. The basal diameter of a branch $B b$ was recorded at the base. The apical diameter of the branches $(B a)$ and the stem (Sa) were measured below a dormant bud. Stem length $(H)$ and branch length $(l)$ were measured with a ruler from the base to below a winter bud (accuracy of $0.1 \mathrm{~cm}$ ).

This article is protected by copyright. All rights reserved. 


\section{Biomass models}

\section{Sampling and independent variables}

We expressed tree growth as total aboveground woody biomass using an allometric equation. This equation estimated the aboveground woody biomass from non-destructive measurements of easily measured variables (e.g. basal diameter). This model was constructed using a total of 95 additional saplings per species collected from the donor site and harvested. The allometric equation based on these additional saplings served to estimate the biomass of the saplings included in the study in a non-destructive way. Tree components (stem, four longest branches, remaining branches and roots) were separated in the laboratory and placed in paper bags. $S a, S b, H, B a, B b$ and $l$ were measured on the stems and main branches, which were then oven-dried at $65{ }^{\circ} \mathrm{C}$ to constant weights. These independent variables and their combinations (e.g. stem diameter and height) were then correlated with the total dry weight (g) using linear regressions to obtain the most parsimonious model.

\section{Model construction and validation}

Several criteria were followed for selecting the optimal allometric equation for each species: (1) the highest adjusted coefficient of determination ( $R^{2}$ adj), (2) the lowest root-mean-square error RMSE, (3) $F<0.05$, (4) the regression model with the best biomass estimates for both species and (5) and the practicality of the model (cost of measuring the independent variables).

The selected model indirectly estimated the aboveground biomass using the total volume of the stem and the four main branches (Eq. 1). This method was the best for quantifying and comparing the aboveground biomass of the two species with different growth patterns (i.e. beech growing in height and spruce producing more branches). The model developed was:

$$
\operatorname{Ln}(\mathrm{B})=\mathrm{c}+\mathrm{aLn}(\mathrm{V}) \text { Eq. (1) }
$$

where $\mathrm{B}$ is the aboveground woody biomass $(\mathrm{g}), \mathrm{V}$ is the total volume of the four main branches and stem $\left(\mathrm{cm}^{3}\right)$ and $\mathrm{c}$ is the intercept and a is the slope coefficient of the regression line. The allometric equation for beech was $B=\exp ^{\wedge}(1.012535 *(\operatorname{Ln}(\mathrm{V}))-0.585528)$, with an $R^{2}$ adj of 0.995 and $P<0.0001$. The model for spruce was $\mathrm{B}=\exp ^{\wedge} 1.00926 *(\mathrm{LnV})$, with an $R^{2}$ adj of 0.997 and $P<0.0001$. The model selected for each species was then validated with half of the saplings used in the study harvested in autumn 2014 during the transplantation to larger pots.

This article is protected by copyright. All rights reserved. 
We used these models to calculate the initial and final biomasses of each sapling for each growing season. The difference between the final and initial biomasses was divided by the initial biomass to normalize for sapling size, allowing the removal of any possible effect of sapling size.

\section{Definition of length of the growing season}

\section{Onset of the vegetative period}

Phenological variables were observed along the elevational gradient during the entire study period. Leaf emergence was monitored in spring every 2-3 days by the same observer. The developmental stages that were chosen were based on Vitasse (2009). The stages for beech were: (0) dormant buds, (1) swollen and/or elongated buds, (2) budburst and (3) at least one fully unfolded leaf. The stages for spruce were: (0) dormant buds, (1) expanded buds with new green visible behind the transparent cupule and (2) unfolded needles. The date of leaf unfolding was defined as the date when $50 \%$ of the buds had reached this stage.

\section{End of the vegetative period}

Leaf coloring and/or leaf fall in autumn were the criteria used to assess the senescence of beech leaves and therefore the end of the vegetative period. Senescence was defined as the time when $50 \%$ of the leaves of a sapling were no longer functional, i.e. either colored or fallen, using the equation (Vitasse, 2009):

$$
x_{t}=\frac{a_{t} \times\left(100-\beta_{t}\right)}{100}+\beta_{t} \text { Eq. (2) }
$$

where $x_{t}$ is the percentage of colored or fallen leaves for a sapling at time $t, \alpha_{t}$ is the percentage of colored leaves at time $t$ and $\beta_{t}$ is the percentage of missing leaves at time $t$.

Norway spruce is an evergreen coniferous tree, so determining the exact end of the vegetative period is challenging. We therefore also monitored budset for both species three times per week from August to October in 2014 and 2015. The stages recorded were: (0) ongoing leaf development, (1) newly formed green and soft buds, (2) small and brown buds and (3) elongated $(>1 \mathrm{~cm})$ and brown buds. The time of budset was recorded when $50 \%$ of the buds of a sapling had reached stage 3. The two proxies used for the definition of the cessation of primary growth were compared for beech to further understand bud formation and hardening before winter. 


\section{Length of the growing season}

We defined the length of the beech growing season as the number of days between the date of leaf unfolding and the date of leaf senescence. We assumed that spruce ended its primary growth at beech senescence at the latest (see Results). The mean dates of beech senescence were thus calculated per site and year and assigned to the corresponding site and year of the spruce saplings. The length of the spruce growing season was consequently defined as the number of days between needle unfolding and the corresponding mean date of beech senescence.

\section{Defining mean climatic variables}

We took into consideration three mean climatic variables to explain the tree growth observed (Table 1): mean air temperature during the growing season $\left(\mathrm{T}_{\text {mean }}\right)$, the precipitation rate per day (Rain mm/day) and the soil moisture by measurements of volumetric water content in the soil (VWC, $\mathrm{m}^{3} / \mathrm{m}^{3}$ ) during the growing season between the months of May and July of each year (primary growth was mainly suppressed at the end of the summer (August) when the winter bud formation takes place; Fig. 1). For the VWC measurements, we used sensors 5TM (Decagon S.A) placed at $20 \mathrm{~cm}$ soil depth measuring at hour resolution. Soil moisture was also monitored weekly by means of a TDR probe (Time Domain Reflectometry) from May to September but these data were not considered for the mean climatic variables as they covered only the vegetation season 2013 and 2014 (See Figure S1).

\section{Defining climatic extremes}

There is no accurate definition related to the existence of an "extreme" (Stephenson, 2008). An established definition would be "an episode or occurrence in which a statistically rare or unusual climatic period alters ecosystem structure and/or function well outside the bounds of what is considered typical or normal variability" (Smith, 2011). A special report of IPCC (Murray \& Ebi, 2012) defined an "extreme climate or weather event" or "climate extreme" as "the occurrence of a value of a weather of climate variable above (or below) a threshold value near the upper (or lower) ends of the range of observed values of the variable". They clarify the definition by stating that it includes absolute thresholds as extreme events and give the example of specific critical temperatures for health impacts.

In this study, we defined "extreme" as done by IPCC (Murray \& Ebi, 2012). We established impact-related thresholds in beech and spruce performance for saplings growing in the Swiss Jura. The thresholds were based in thermal-hydric requirements of each species. Vapor- 
pressure deficit (VPD) is a measure of the difference between the pressure exerted by the moisture currently in the air and the pressure at saturation. We calculated the VPD, as a measure of the drying power of the air, as follows:

$$
\mathrm{VPD}=(1-(\mathrm{RH} / 100) * \mathrm{SVP} \text { Eq. (3) }
$$

where $\mathrm{RH}$ is the relative humidity and SVP is the saturated vapor pressure for a given temperature.

A VPD threshold of $1.5 \mathrm{kPa}$ was chosen to represent the approximate value above which stomata close in both species (Kurjak et al., 2012; Lendzion \& Leuschner, 2008; Zweifel, Bohm, \& Hasler, 2002). We used this VPD to represent the extremely dry air during an extended summer drought. Heat waves and cold spells were represented by two predefined temperature thresholds: above $25^{\circ} \mathrm{C}$ and below $5^{\circ} \mathrm{C}$. The superior threshold $\left(25^{\circ} \mathrm{C}\right.$ during the vegetative period), was based on the thermal requirements of the two species (Gelete, 2010). Additionally, photosynthesis a temperature-response curve performed in saplings growing at the extremes sites revealed that from $25^{\circ} \mathrm{C}$ the net photosynthesis starts to decline for both species. The lower limit was established at $5^{\circ} \mathrm{C}$ as it appears to be the limit for higher plant tissue growth (Körner, 2008). We thus calculated i) the accumulation of hours over threshold $25^{\circ} \mathrm{C}$ (AOT25) during the growing season and ii) the accumulation of hours below threshold $5^{\circ} \mathrm{C}$ (ABT5). We also calculated the number of events with thirty consecutive days without rain during the growing season at each site (P30).

\section{Statistical analysis}

General additive mixed effects models (GAMMs) were used to explore the response of aboveground tree biomass to changing climate over time. Briefly, GAMMs allow the change in mean biomass to follow any smooth curve, not just a linear form or a sequence of unrelated estimates. The form of the predictor function is the principal difference between the classical generalized mixed-effects models and GAMMs. All models were fitted according to a Gaussian distribution. We assessed five fixed effects (mean climate and extreme events) and one random effect (site nested into date) to take into account the inflation of the residual degrees of freedom that would occur if we were using repeated measurements within sites as true replicates. Several combinations of models were tested to find the most parsimonious model that would best explain the biomass response. We used Akaike's Information Criterion (AIC) (Akaike, 1973), $\mathrm{R}^{2}$ adj and the normality of residuals to compare the different models. As explanatory variables, we included soil moisture $\left(\mathrm{m}^{3} / \mathrm{m}^{3}\right)$ along with the other "average"

This article is protected by copyright. All rights reserved. 
variables $\mathrm{T}_{\text {mean }}\left({ }^{\circ} \mathrm{C}\right)$, Rain ( $\mathrm{mm} /$ day) and the defined "extreme" temperature variables AOVPD1.5 (hours) and ABT5 (hours). According to Dormann's et al. review (2013), correlation coefficients between variables of $|r|>0.7$ is an appropriate indicator for when collinearity begins to severely distort model estimation. Therefore, for all models, we ensured that none of the explanatory variables were correlated between each other with a Pearson's correlation coefficient higher than 0.7 , which gives us relatively good confidence that collinearity among predictors is not affecting our inference. Using effect size (Eq.4) allowed us to quantify the impact of changing environmental conditions on the growth of the transplanted saplings. All statistical analyses were performed in R 3.1.2 using the $m g c v$ package.

$$
\text { Effsize }[i]=\frac{x[i]-\overline{x_{c}}}{\sigma x_{c}} \text { Eq. (4) }
$$

where $x$ is the variable considered for each observation [i], $\bar{x}_{c}$ and $\sigma x_{c}$ are the mean and standard deviation of the control population.

We measured the interannual climatic variability along the elevational gradient to identify the factors influencing tree growth (Table 1). The wireless meteorological stations continuously recorded the climatic parameters needed for calculating the duration of extreme events. Data from nearby stations were used when necessary to complete the data set (Agroscope, 2016). The climatic variables were calculated individually for each sapling as a function of the growing season.

\section{Results}

\section{Interannual climatic variability}

The elevational gradient provided a distinct climatic gradient, with warmer and drier conditions towards the lower sites (Table 1). The mean annual temperature increased by an average of $5.5^{\circ} \mathrm{C}$ between the highest and lowest sites during the study period. Precipitation was 20 to $47 \%$ (data not shown) lower at the two lower sites compared to the donor site. The number of cold days (ATB5) was generally considerably higher at 1350 and $1010 \mathrm{~m}$ than at 570 and $395 \mathrm{~m}$, and the number of warm days (ATO25) had the opposite trend. The lower altitudes had warmer conditions, but precipitation was not linear along the elevational 
gradient. Precipitation varied widely between years, and the saplings received considerable rainwater during spring and summer, despite the lower rainfall at the lower altitudes (especially in 2015).

Higher mean temperatures during the 2015 growing season led to a higher evaporative demand compared to the two previous years. For example, the accumulation of hours of VPD $>1.5 \mathrm{kPa}$ (AOVPD1.5) in the growing season 2015, were 107, 220, 444 and 366, respectively at 1350,1010, 570 and $395 \mathrm{~m}$, but were 41,33, 65 and $92 \mathrm{~h}$, respectively, at the same sites in the previous year (Table 1). Mean temperatures, however, were not always a good indicator of the dryness of the air. The mean temperatures at the lowest site during the 2013 and 2014 beech growing seasons were 16.5 and $16.1^{\circ} \mathrm{C}$, respectively, but AOVPD1.5 was 2.5-fold higher in 2013 than 2014. Similarly, the mean temperatures at $570 \mathrm{~m}$ during the 2013 and 2015 beech growing seasons were 17.6 and $17.2^{\circ} \mathrm{C}$, and the corresponding AOVPD1.5 were 160 and $444 \mathrm{~h}$, respectively.

\subsubsection{Comparison of soil moisture along the gradient}

Globally, we observed a soil moisture gradient between the highest $(1350 \mathrm{~m}$ and $1010 \mathrm{~m})$ and the lowest (395 m and $570 \mathrm{~m}$ ) sites (Table 1, see also supplementary Fig. S1). This gradient was notable during the growing season 2015 .

\section{Phenological responses to the simulated conditions of climate change}

Spring phenology shifted along the elevational gradient for both species (Fig. 1). Budburst was delayed towards the higher altitudes by averages of $\sim 4.8 \mathrm{~d}^{-100 \mathrm{~m}^{-1}}( \pm 0.16)$ and $4.0 \mathrm{~d}$ $100 \mathrm{~m}^{-1}( \pm 0.42)$ for beech and spruce, respectively. Autumn phenology, i.e. budset and leaf senescence, tended to occur later at the lower altitudes, but the pattern was more variable and less pronounced than for budburst. Overall, a decrease in elevation extended the growing season. The growing season length (GSL) at 1350 and $395 \mathrm{~m}$ over the three years averaged $115 \pm 10 \mathrm{~d}$ (mean $\pm 1 \mathrm{SE}$ ) and $179 \pm 3 \mathrm{~d}$ for beech and $113 \pm 10$ and $165 \pm 3 \mathrm{~d}$ for spruce, respectively. Interestingly, the interannual variation of GSL was higher at the donor than the lowest site for both species, at \pm 10 and \pm 3 at 1350 and $395 \mathrm{~m}$, respectively.

The time lag between budset and senescence varied between years. For example, budset for both species in 2014 was very advanced compared to beech senescence, but budset and senescence in 2015 occurred at nearly the same time.

This article is protected by copyright. All rights reserved. 


\section{Growth responses to the simulated conditions of climate change}

Exposure to the warmer and drier conditions at the lower altitudes for three years had contrasting effects on beech and spruce saplings from $1350 \mathrm{~m}$ (Fig. 2). The growth of the spruce saplings did not differ significantly along the elevational gradient, but beech growth increased significantly between the donor and lower altitudes (Fig. 2a). Growth increased more for spruce than beech at $1350 \mathrm{~m}$ but more for beech than spruce at $395 \mathrm{~m}$. Standardizing the growth data by the growing season length produced similar patterns, which varied with altitude and species (Fig. 2b).

\section{Effect size for tree growth under warmer and drier conditions}

The transplantation to warmer and drier conditions generally had a positive impact on beech growth and a negative impact on spruce growth. The growth of the beech saplings from 1350 m differed significantly between 2013 and 2015 (Fig. 3a), but the tree effect size was similar along the gradient in 2014 , with an overall very positive effect relative to the donor site. We also observed a species-specific effect size at the same altitude. The effect size was mostly positive for beech but was negative for spruce (except in 2014). The irrigation treatment significantly mitigated the lower soil moisture, thus negative impact of warming on spruce growth in $2015(p=0.001)$.

\section{Impacts of the extreme climatic conditions on sapling growth}

The relationship between effect size for growth and the measured extreme conditions identified a distinct interannual climatic variability (Fig. 4). The AOVPD1.5 was lowest in 2014, whereas 2015 had the longest period of dry air during the growing season, with more than $400 \mathrm{~h}$ of AOVPD1.5. The effect size was negative beyond $300 \mathrm{~h}$ of AOVPD1.5 for beech and beyond $100 \mathrm{~h}$ for spruce. The effect size for cold days was negative for beech in 2013, with growth decreasing as the number of cold days increased. In contrast, the effect size for spruce had no clear pattern, suggesting that other variables limited its growth. The irrigation treatment mitigated the negative effect of increasing VPD, especially for spruce during the dry 2015 growing season.

The results from GAMM models of beech showed that the model including only mean variables (i.e. Rain, $\mathrm{T}_{\text {mean }}$ and Soil VWC; model 1) was the less accurate for explaining beech saplings' growth. However, when considering the extreme variables (i.e. ABT5 and AOVPD1.5), we observed an important increase in the explanation of beech biomass with a 
$\mathrm{R}^{2}>0.75$ (model 2). Moreover, replacing the AOVPD1.5 by Soil VWC, in order to answer the question whether it is VPD and not soil moisture that best explains the growth patterns observed, showed a significant drop in the model performance for both species (models 3 and 6). Models explained in lesser extent the growth patterns of spruce than those of beech, with still a higher model performance when considering only the extreme climatic variables $\left(\mathrm{R}^{2}=\right.$ 0.40 ; model 5) and none of the models presented a significant effect of soil moisture (Table 2).

\section{Discussion}

Transplanting saplings to lower elevation provides crucial insights on how trees in their juvenile life stage will face climate change. The analysis of growth response over contrasted climatic conditions from year to year allowed us to differentiate responses due to mean over extreme climatic conditions. Here, focusing on growth performances, we showed that beech saplings may benefit from warmer conditions and even drier conditions, whereas spruce seems already constrained by water limitation and air dryness (VPD) at low elevations of the Jura mountains. The higher sensitivity of spruce to increasing VPD, compared to beech, likely explain its limited growth at the lower elevations. This study highlights the importance to account for the effects of extreme climatic events when assessing the impact of climate warming on tree performance because these events are likely to deviate from the overall expected growth response to change in the mean climatic conditions.

\section{Contrasting growth responses of beech and spruce saplings exposed to simulated climate change}

Beech and spruce saplings' growth was differently affected when transplanted towards lower elevations during the three monitored years. In these drier and warmer conditions, beech growth was significantly enhanced, whereas spruce growth was similar to the growth at the native higher elevation site. The extension of the growing season may explain such tendencies. Our phenological observations showed a lengthening of the growing season towards the lower altitudes for both species, regardless of the proxy used for the end of the growing season (budset or beech senescence). The time lag between budset and senescence varied between years. For example, budset for both species was substantially advanced in 2014 compared to beech senescence, but budset and senescence occurred at nearly the same time in 2015 , likely influencing the effective period of nutrient mobilization. The growing season was nonetheless consistently longer at the lower altitudes, which may partly account

This article is protected by copyright. All rights reserved. 
for the increase in beech biomass at the lower altitudes, as also suggested by Lenz et al. (2014), but does not account for the patterns of spruce growth. However, we found similar responses to warming when standardizing the growth data by the length of the growing season. Increasing the length of the growing season thus had a positive effect on tree growth only to a certain limit, which was species-dependent. This suggests that additional factors (e.g. air temperature, VPD, nutrient turnover) than phenological variations promoted beech growth while limiting spruce growth at lower elevations.

The continuum of soil-plant-atmosphere is critical for tree growth and their respective impacts in tree growth are very difficult to disentangle. However, depending on the site conditions there is always one factor being more limiting than the others. In this study, we aimed to find which factors explained best tree growth variation during years with contrasted climate and at different elevations. Because the two species are known to be sensitive to drought, one may expect that the transplantation of saplings to lower elevations with warmer and drier conditions would expose them to water deficits and limit their growth. However, we found that saplings were not water limited at the lower sites during the growing seasons 2013 and 2014, which was also supported by the ecophysiological measurements of leaf water potential (see supplementary Table S1).

To answer the question as to whether it is VPD and not soil moisture that best explains beech growth responses, we can compare the performance of models 2 and 3 and see that the replacement of the VPD explanatory variable (AOVPD1.5) by the soil moisture explanatory variable (Soil VWC) even decreases the overall performance of the model. Therefore, by including the soil moisture variable (model 3), we did not add any valuable information to the model. To sum up, model 2, which includes only "extreme variables" (ABT5, AOVPD1.5) best explained the growth response of beech with a $\mathrm{R}^{2}$ of 0.77 . All explanatory variables were significant; the residuals of the model followed a normal distribution, and AIC and BIC were the lowest compared to the other models. Generally, models explained in lesser extent the growth patterns of spruce than the growth patterns of beech, suggesting that other factors, not taken into account in this study, may explain part of spruce's biomass variance, and none of the models presented a significant effect of the soil moisture. Following the same logical procedure than beech, we found that model 5, including only the "extreme" variables, had a higher $\mathrm{R}^{2}$ adj coefficient (0.4). In conclusion, GAMM models showed that soil moisture was 
not a significant factor explaining tree growth in this humid area of study. Interestingly, the "extreme" climatic variables, ABT5 and AOVPD1.5, significantly explained tree growth and even more than the models integrating exclusively "average" variables, such as mean temperature.

Growth rates between years revealed an interannual variability within species (Fig S2). The growth patterns of beech showed that in 2013 and 2014 tree growth was higher at the lowest elevation compared to the control site. In the growing season 2015, beech saplings grew at the same rate along the gradient except at $1010 \mathrm{~m}$. In contrast, spruce showed a decrease in growth rate at lower altitudes compared to the control site, for years 2013 and 2015. Yet, interestingly higher growth rates were observed at lower altitudes (Fig S2 blue rectangle) during the growing season 2014, in spite of the lower soil moisture and lower amount of precipitation recorded during this year. Regarding atmospheric conditions, average temperatures during the growing season hardly differed in 2013 and 2014, but significantly differed in the amount of hours during which saplings were exposed to elevated VPD. It has been hypothesized that VPD may trigger stomatal closure to avoid an excess of water loss due to high evaporative demand of the air (Carnicer et al., 2013). The degree of sensitivity of stomatal closure to elevated VPD is highly species-specific. Two main hydraulic functional groups have been distinguished in the literature depending on their strategies to cope with higher evaporative demand (Bond \& Kavanagh, 1999; Carnicer et al., 2013). Isohydric trees (e.g. spruce) avoid drought-induced hydraulic failure via stomatal closure, reducing the carbon assimilation (McDowell et al., 2008; Carnicer et al., 2013). This greater stomatal control maintains a relatively constant day-time leaf water potential (see supplementary Table S1). This allows them to prevent leaf water potential from falling below a threshold associated with cavitation (McDowell et al., 2008; Pangle et al., 2015) Typically, anisohydric tree species are associated with a higher ability to reverse embolisms leading to this narrower hydraulic safety margins compared to isohydric species (Carnicer et al., 2013). Therefore, the difference in amount of hours with elevated VPD to which saplings were exposed in this study may cause important physiological responses and cannot be disregarded.

Our findings show that beech and spruce respond differently to high VPD. Leaf water potential of these species also revealed different patterns of regulating water transpiration (see supplementary Table S1). It is known from literature that species may exhibit intraspecific variation in degree of anisohydricity or isohydricity (Cocozza et al., 2016) meaning that no species is strictly anisohydric or isohydric. However, in our study, beech did 
present a more anisohydric behavior than spruce (see supplementary Table S1). Therefore, we suggest that the different responses to elevated VPD could be linked to a difference in isohydric behavior.

This hypothesis is in agreement with a previous study carried out in a mixed forest in Pennsylvania, where the authors assessed the stomatal sensitivity to VPD of seven cooccurring temperate tree species (Meinzer et al., 2013). They found that ring-porous species had a lower stomatal responsiveness to VPD than the diffuse-porous and coniferous species. In this paper, they suggest that these findings are linked to the isohydric behavior of the diffuse-porous and coniferous species, and the rather extreme anisohydric behavior in oaks.

Our results show that increasing VPD limits tree growth even before soil moisture starts to be limiting. Moreover, tree growth reduction is greater when both VPD and soil moisture reach limiting thresholds. The key finding of this paper is the demonstration of the different degree of sensitivity of these species to increasing VPD. The degree of isohydricity of these two species is likely to be linked to this different sensitivity.

Many other authors have hypothesized that contrasting growth responses between angiosperms and gymnosperms are due to the different sensitivities of their stomatal conductance to vapor pressure deficit, leading to contrasting growth responses (MartínezFerri et al., 2000; Brodersen et al., 2010; Carnicer et al., 2013; Coll et al., 2013; Meinzer et al., 2013). In contrast, Martínez-Vilalta and Garcia-Forner (2016) have recently argued that water potential regulation and stomatal behavior are decoupled across species, so it remains today as an open debate whether isohydric and anisohydric trees lead to different responses to VPD. Further research in this topic is warranted.

\section{The use of means and extremes for analysing the impact of interannual climatic variability on the growth responses of the saplings}

Growth responses are commonly correlated with mean temperatures (Bowman, Williamson, Keenan, \& Prior, 2014; Jump, Hunt, \& Peñuelas, 2006; Lévesque, Rigling, Bugmann, Weber, \& Brang, 2014; Miyamoto et al., 2010; Way \& Oren, 2010). Mean annual temperature in our study differed by ca. $5.5^{\circ} \mathrm{C}$ between the native and lowest sites. Growth of saplings inhabiting high elevation $(1350 \mathrm{~m})$ are likely to be limited by temperature and we expect warmer temperatures to elicit positive effects on growth, in the absence of water stress (Way \& Oren, 2010). Yet, growth was not enhanced for spruce when transplanted towards lower elevations

This article is protected by copyright. All rights reserved. 
in contrast to beech. This difference in response may root in different sensitivity of the two species to extreme climatic conditions, in particular to high VPD, which can be observed by analyzing growth response of the two species to interannual climatic variations.

For instance, cold spells at the beginning of the season were about twice as long in 2013 as in the other two years. Important precipitation deficits were further observed in the two lowest sites for more than 30 consecutive days (at $570 \mathrm{~m}$ in 2013 and at $395 \mathrm{~m}$ in 2015) compared to the native site. Thus, the mean interannual climatic variability of $2^{\circ} \mathrm{C}$ did not fully explain tree growth pattern because it hides substantial variations in the extreme climatic values and their frequency. The mean temperature during the growing season at the lowest site $(395 \mathrm{~m})$ was similar in 2013 and 2014 , with 16.5 and $16.1^{\circ} \mathrm{C}$, respectively, which was $3.8-4.8^{\circ} \mathrm{C}$ higher than at the donor site. The quantification of the effect size, however, identified contrasting growth responses for spruce between these two years: the effect size was negative in spruce's growth response to warming in 2013 whilst a positive effect size was found in 2014. Spruce saplings were subjected to 228 hours of AOVPD1.5 at the lowest site in 2013, which is more than twice as much as in 2014 (92 hours). An exceedance in VPD above the threshold of $1.5 \mathrm{kPa}$ can stimulate the closure of stomata in spruce (Kurjak et al., 2012; Zweifel et al., 2002). Assuming that there is a reduction in carbon up take, or even suppression depending on the degree of stomatal closure, these results suggest that spruce growth was limited by a large amount of VPD hours above $1.5 \mathrm{kPa}$ in 2013 but not in 2014 . Spruce is more sensitive to VPD increases than beech as it closes rapidly its stomata to reduce hydraulic conductivity before substantial cavitation occurs. By contrast, stomatal conductance in beech, an angiosperm, can remain high even at very high evaporative demands due to its higher capacity to reverse embolisms (Carnicer et al., 2013).

Saplings' growth transplanted at $1010 \mathrm{~m}$ were likely constrained by temperature (Koch, 1958; Modrzyński \& Eriksson, 2002). There was a strong contrasting growth response for beech between 2013 and 2014 at this site associated to the $2^{\circ} \mathrm{C}$ difference in mean temperature during the two growing seasons, i.e. warmer temperature during summer 2014 may have contributed to enhance beech growth. Conversely, the growth of the saplings at the lowest sites was likely strongly limited by water in 2015 . Rainfall was $47 \%$ lower at $395 \mathrm{~m}$, accompanied by an increase in AOVPD1.5 of $259 \mathrm{~h}$ compared to the donor site. A water deficit also occurred at the treatment level; irrigation had a lower negative impact on the growth response, i.e. the impact of a water deficit in 2015 for spruce was mitigated by the irrigation treatment $(P=0.001)$.

This article is protected by copyright. All rights reserved. 


\section{Difference in species sensitivities to extreme conditions due to different tolerance thresholds}

The quantitative assessment of the impacts of an increase in the AOVPD1.5 and ABT5 on tree growth provided new insights for assessing climate-growth relationships. The higher sensitivity of spruce than beech to increasing VPD could account for the limited growth of spruce at the lower altitudes. We used a scatterplot of VPD vs. growth effect size to determine the approximate upper limit threshold for each species. The lower tolerance limit of spruce $(\sim 100 \mathrm{~h})$ compared to beech $(\sim 300 \mathrm{~h})$ partly could account for the contrasting growth responses between these species. The negative impacts of extreme conditions also depended on the conditions of the site, i.e. the impact on growth was not the same at 1010 and $395 \mathrm{~m}$ for the same duration of increased VPD, mainly due to the differences in the limitation of tree growth at higher and lower altitudes (temperature vs. water deficit). The absence of a clear response of spruce to the length of cold spells during the growing season suggested that spruce growth was limited by other variables. In contrast, beech growth was negatively affected by an ABT5 above $200 \mathrm{~h}$ during the growing season. The large range of responses of both species under this threshold of $200 \mathrm{~h}$ indicated that lower temperatures were not the main limitation to growth at the recipient sites. Our results suggest that both spruce and beech are limited by increasing air dryness but present different degrees of tolerance. The final GAMMs identified VPD as the main explanatory variables of the increases in biomass for both species. As second main explanatory variable the precipitation rate during the growing season (mm/day GS) was determinant factor for beech while the number consecutive days without precipitation during the growing season was for spruce. This leads to a differentiation between the main factor which is common for both species (VPD) and more species-dependent factors related to precipitation and consecutive days without rain.

We conclude that elevated vapor deficit limits tree growth. Our results showed that (i) a longer growing season due to induced-elevation warming (downward shift) could not fully account for the species-specific positive growth responses; (ii) the contrasting species growth responses were linked to different sensitivities to elevated vapor-pressure deficits; (iii) models could better account for the growth response to warming after incorporating extreme climatic events and their effects. On the top of that, for the first time we determined the threshold above which tree growth starts to decline for each species when soil moisture was not limiting. It is however likely that if soil moisture would have been lower during these

This article is protected by copyright. All rights reserved. 
high VPD conditions saplings growth would have been further reduced. Finally, the inclusion of climate extremes will likely improve models predicting species distribution under future climatic conditions (Zimmermann et al., 2009). The potential extrapolation of this approach and results, through further research on adult trees, will be crucial for a better understanding of forest response to climate change and for adapting forest management to the predicted increase in duration and in frequency of extreme climate conditions.

\section{Acknowledgements}

We want to thank the Masters students Felix Hernandez, Matthieu Bidon, Ester Toledano and Rocío Mijancos and the civilists Sylvain Vitali, Lucas Wettstein, Adrian Pulgarin and Timothée Lottaz for their help during the laboratory and field work. The work was supported by WHFF Wald- und Holzforschungsfonds (BAFU), the Forschungsprogramm Wald und Klimawandel (BAFU-WSL) and the Foundation Les Bois-Chamblard (EPFL). Josep Peñuela's research was supported by the European Research Council Synergy grant ERC2013-SyG 610028-IMBALANCE-P

\section{References}

Agroscope. (2016). Agrometeo. Retrieved from http://www.agrometeo.ch/

Akaike, H. (1973). Information theory and an extension of the maximum likelihood principle. In International Symposium on Information Theory (pp. 267-281). http://doi.org/10.1016/j.econlet.2011.12.027

Allen, C. D., Breshears, D. D., \& McDowell, N. G. (2015). On underestimation of global vulnerability to tree mortality and forest die-off from hotter drought in the Anthropocene. Ecosphere, 6(8), art129. http://doi.org/10.1890/ES15-00203.1

Allen, C., Macalady, A., Chenchouni, H., Bachelet, D., Mcdowell, N., Vennetier, M., ... Cobb, N. (2010). A global overview of drought and heat induced tree mortality reveals emerging climate change risk for forests. Forest Ecology and Management, 259(4), 660-684.

http://doi.org/10.1016/j.foreco.2009.09.001

Bond, B. J., \& Kavanagh, K. L. (1999). Stomatal behavior of four woody species in relation to leafspecific hydraulic conductance and threshold water potential. Tree Physiology, 19(8), 503-510. http://doi.org/10.1093/treephys/19.8.503

Bowman, D. M. J. S., Williamson, G. J., Keenan, R. J., \& Prior, L. D. (2014). A warmer world will reduce tree growth in evergreen broadleaf forests: Evidence from Australian temperate and subtropical eucalypt forests. Global Ecology and Biogeography, 23(8), 925-934. http://doi.org/10.1111/geb.12171

Brodersen, C. R., McElrone, A. J., Choat, B., Matthews, M. A., Shackel, K. A. (2010) The Dynamics

This article is protected by copyright. All rights reserved. 
of Embolism Repair in Xylem: In Vivo Visualizations Using High-Resolution Computed Tomography. Plant Physiology, 154, 1088-1095.

Brodribb, T. J., \& McAdam, S. A. M. (2011). Passive Origins of Stomatal Control in Vascular Plants. Science, 331(6017), 582-585. http://doi.org/10.1126/science.1197985

Buttler, A. (2014). Grasslands in silvopastoral mountain ecosystems. In Grassland Biodiversity and Conservation in a Changing World (pp. 187-218).

Carnicer, J., Barbeta, A., Sperlich, D., Coll, M., \& Penuelas, J. (2013). Contrasting trait syndromes in angiosperms and conifers are associated with different responses of tree growth to temperature on a large scale. Frontiers in Plant Science, 4, 409. http://doi.org/10.3389/fpls.2013.00409

Ciais, P., Reichstein, M., Viovy, N., Granier, A., Ogée, J., Allard, V., ... Valentini, R. (2005). Europewide reduction in primary productivity caused by the heat and drought in 2003. Nature, 437(7058), 529-533. http://doi.org/10.1038/nature03972

Cocozza, C., de Miguel, M., Pšidová, E. et al. (2016) Variation in Ecophysiological Traits and Drought Tolerance of Beech (Fagus sylvatica L.) Seedlings from Different Populations. Frontiers in Plant Science, 7, 886.

Coll, M., Peñuelas, J., Ninyerola, M., Pons, X., Carnicer, J. (2013) Multivariate effect gradients driving forest demographic responses in the Iberian Peninsula. Forest Ecology and Management, 303, 195-209.

Damour, G., Simonneau, T., Cochard, H., \& Urban, L. (2010). An overview of models of stomatal conductance at the leaf level. Plant, Cell and Environment. http://doi.org/10.1111/j.13653040.2010.02181.x

De Boeck, H. J., Dreesen, F. E., Janssens, I. A., \& Nijs, I. (2010). Climatic characteristics of heat waves and their simulation in plant experiments. Global Change Biology, 16(7), 1992-2000. http://doi.org/10.1111/j.1365-2486.2009.02049.x

Delpierre, N., Guillemot, J., Dufrêne, E., Cecchini, S., \& Nicolas, M. (2017). Tree phenological ranks repeat from year to year and correlate with growth in temperate deciduous forests. Agricultural and Forest Meteorology, 234, 1-10.

Dormann, C. F., Elith, J., Bacher, S., Buchmann, C., Carl, G., Carré, G., ... Lautenbach, S. (2013). Collinearity: A review of methods to deal with it and a simulation study evaluating their performance. Ecography, 36(1), 027-046. http://doi.org/10.1111/j.1600-0587.2012.07348.x

Franks, P. J., \& Farquhar, G. D. (1999). A relationship between humidity response, growth form and photosynthetic operating point in C3 plants. Plant, Cell and Environment, 22(11), 1337-1349. http://doi.org/10.1046/j.1365-3040.1999.00494.x

Fu, Y. H., Piao, S., Op de Beeck, M., Cong, N., Zhao, H., Zhang, Y., ... Janssens, I. A. (2014). Recent spring phenology shifts in western Central Europe based on multiscale observations. Global Ecology and Biogeography, 23(11), 1255-1263. http://doi.org/10.1111/geb.12210

Gavazov, K. S., Peringer, A., Buttler, A., Gillet, F., \& Spiegelberger, T. (2013). Dynamics of forage production in pasture-woodlands of the Swiss Jura mountains under projected climate change scenarios. Ecology and Society, 18(1). http://doi.org/10.5751/ES-04974-180138

Gavazov, K., Spiegelberger, T., \& Buttler, A. (2014). Transplantation of subalpine wood-pasture turfs along a natural climatic gradient reveals lower resistance of unwooded pastures to climate change compared to wooded ones. Oecologia, 174(4), 1425-1435.

http://doi.org/10.1007/s00442-013-2839-9

This article is protected by copyright. All rights reserved. 
Gelete, D. C. (2010). Modelling the Potential Ecological Niche of Fagus (Beech) Forest in Majella National Park, Italy. International Institute for geo-information science and earth observation, The Netherlands. Retrieved from https://www.itc.nl/library/papers_2010/msc/nrm/desalegn.pdf

Hanson, C. E., Palutikof, J. P., Dlugolecki, A., \& Giannakopoulos, C. (2006). Bridging the gap between science and the stakeholder: The case of climate change research. Climate Research. http://doi.org/10.3354/cr031121

IPCC. (2013). IPCC Fifth Assessment Report (AR5). IPCC.

Jolly, W. M., Dobbertin, M., Zimmermann, N. E., \& Reichstein, M. (2005). Divergent vegetation growth responses to the 2003 heat wave in the Swiss Alps. Geophysical Research Letters, 32(18), 1-4. http://doi.org/10.1029/2005GL023252

Jump, A. S., Hunt, J. M., \& Peñuelas, J. (2006). Rapid climate change-related growth decline at the southern range edge of Fagus sylvatica. Global Change Biology, 12(11), 2163-2174.

Keenan, R. J. (2015). Climate change impacts and adaptation in forest management: a review. Annals of Forest Science. http://doi.org/10.1007/s13595-014-0446-5

Koch, H. G. (1958). Der Holzzuwachs der Waldbäume in verschiedenen Hähenlagen Thuringens in Abhängichkeit von Neiderschlag und Temperatur. Arch. Forstwes., 7, 27-49.

Kolářová, E., Nekovář, J., \& Adamík, P. (2014). Long-term temporal changes in central European tree phenology (1946-2010) confirm the recent extension of growing seasons. International Journal of Biometeorology, 58(8), 1739-1748. http://doi.org/10.1007/s00484-013-0779-z

Körner, C. (2003). Alpine plant life: functional plant ecology of high mountain ecosystems. Alpine plant life functional plant ecology of high mountain ecosystems (Vol. 21). http://doi.org/10.1659/0276-4741(2001)021[0202:APLFPE]2.0.CO;2

Körner, C. (2007). The use of "altitude" in ecological research. Trends in Ecology and Evolution, 22(11), 569-574. http://doi.org/10.1016/j.tree.2007.09.006

Körner, C. (2008). Winter crop growth at low temperature may hold the answer for alpine treeline formation. Plant Ecology \& Diversity, 1(1), 3-11. http://doi.org/10.1080/17550870802273411

Körner, C. (2017). A matter of tree longevity. Science, 355(6321), 130-131. http://doi.org/10.1126/science.aal2449

Körner, C., Basler, D., Hoch, G., Kollas, C., Lenz, A., Randin, C. F., ... Zimmermann, N. E. (2016). Where, why and how? Explaining the low temperature range limits of temperate tree species. Journal of Ecology, n/a-n/a. http://doi.org/10.1111/1365-2745.12574

Kreyling, J., Jentsch, A., \& Beierkuhnlein, C. (2011). Stochastic trajectories of succession initiated by extreme climatic events. Ecology Letters, 14(8), 758-764. http://doi.org/10.1111/j.14610248.2011.01637.x

Kurjak, D., Střelcová, K., Ditmarová, L., Priwitzer, T., Kmet’, J., Homolák, M., \& Pichler, V. (2012). Physiological response of irrigated and non-irrigated Norway spruce trees as a consequence of drought in field conditions. European Journal of Forest Research, 131(6), 1737-1746. http://doi.org/10.1007/s10342-012-0611-z

Lendzion, J., \& Leuschner, C. (2008). Growth of European beech (Fagus sylvatica L.) saplings is limited by elevated atmospheric vapour pressure deficits. Forest Ecology and Management, 256(4), 648-655. http://doi.org/10.1016/j.foreco.2008.05.008

Lenz, A., Vitasse, Y., Hoch, G., \& Körner, C. (2014). Growth and carbon relations of temperate

This article is protected by copyright. All rights reserved. 
deciduous tree species at their upper elevation range limit. Journal of Ecology. http://doi.org/10.1111/1365-2745.12307

Lévesque, M., Rigling, A., Bugmann, H., Weber, P., \& Brang, P. (2014). Growth response of five cooccurring conifers to drought across a wide climatic gradient in Central Europe. Agricultural and Forest Meteorology, 197, 1-12. http://doi.org/10.1016/j.agrformet.2014.06.001

Lindner, M., Fitzgerald, J. B., Zimmermann, N. E., Reyer, C., Delzon, S., van der Maaten, E., ... Hanewinkel, M. (2014). Climate change and European forests: What do we know, what are the uncertainties, and what are the implications for forest management? Journal of Environmental Management. http://doi.org/10.1016/j.jenvman.2014.07.030

Martínez-Ferri, E., Balaguer, L., Valladares, F., Chico, JM., Manrique, E. (2000) Energy dissipation in drought-avoiding and drought-tolerant tree species at midday during the Mediterranean summer. Tree physiology, 20, 131-138

Martínez-Vilalta, J., Garcia-Forner, N. (2016) Water potential regulation, stomatal behaviour and hydraulic transport under drought: deconstructing the iso/anisohydric concept. Plant Cell and Environment, 40, 962-976.

McAdam, S. A. M., \& Brodribb, T. J. (2015). The Evolution of Mechanisms Driving the Stomatal Response to Vapor Pressure Deficit. Plant Physiology, 167(3), 833-843. http://doi.org/10.1104/pp.114.252940

McDowell, N., Pockman, W. T., Allen, C. D., Breshears, D. D., Cobb, N., Kolb, T., ... Yepez, E. A. (2008). Mechanisms of plant survival and mortality during drought: Why do some plants survive while others succumb to drought? New Phytologist. http://doi.org/10.1111/j.14698137.2008.02436.x

Meinzer, F. C., Woodruff, D. R., Eissenstat, D. M., Lin, H. S., Adams, T. S., McCulloh, K. A. (2013) Above-and belowground controls on water use by trees of different wood types in an eastern US deciduous forest. Tree Physiology, 33, 345-356.

Menzel, a, \& Fabian, P. (1999). Growing season extended in Europe. Nature, 397(6721), 659. http://doi.org/10.1038/17709

Miyamoto, Y., Griesbauer, H. P., \& Scott Green, D. (2010). Growth responses of three coexisting conifer species to climate across wide geographic and climate ranges in Yukon and British Columbia. Forest Ecology and Management, 259(3), 514-523.

http://doi.org/10.1016/j.foreco.2009.11.008

Modrzyński, J., \& Eriksson, G. (2002). Response of Picea abies populations from elevational transects in the Polish Sudety and Carpathian mountains to simulated drought stress. Forest Ecology and Management, 165(1-3), 105-116. http://doi.org/10.1016/S0378-1127(01)00651-X

Mott, K. A., \& Peak, D. (2013). Testing a vapour-phase model of stomatal responses to humidity. Plant, Cell and Environment, 36(5), 936-944. http://doi.org/10.1111/pce

Murray V and Ebi KL (2012) IPCC Special Report on Managing the Risks of Extreme Events and Disasters to Advance Climate Change Adaptation (SREX). Journal of Epidemiology and Community Health, 66, 759-760.

Novick, K. A., Ficklin, D. L., Stoy, P. C., Williams, C. A., Bohrer, G., Oishi, A. C., ... Phillips, R. P. (2016). The increasing importance of atmospheric demand for ecosystem water and carbon fluxes. Nature Climate Change, 1(September), 1-5. http://doi.org/10.1038/nclimate3114

Ogaya, R., \& Peñuelas, J. (2007). Species-specific drought effects on flower and fruit production in a

This article is protected by copyright. All rights reserved. 
Mediterranean holm oak forest. Forestry, 80(3), 351-357.

http://doi.org/10.1093/forestry/cpm009

Pangle, R. E., Limousin, J. M., Plaut, J. A., Yepez, E. A., Hudson, P. J., Boutz, A. L., ... Mcdowell, N. G. (2015). Prolonged experimental drought reduces plant hydraulic conductance and transpiration and increases mortality in a piñon-juniper woodland. Ecology and Evolution, 5(8), 1618-1638. http://doi.org/10.1002/ece3.1422

Piao, S., Friedlingstein, P., Ciais, P., Viovy, N., \& Demarty, J. (2007). Growing season extension and its impact on terrestrial carbon cycle in the Northern Hemisphere over the past 2 decades. Global Biogeochemical Cycles, 21.

Rogers, B. M., Jantz, P., \& Goetz, S. J. (2017). Vulnerability of eastern US tree species to climate change. Global Change Biology. http://doi.org/10.1111/gcb.13585

Sanginés de Cárcer, P., Signarbieux, C., Schlaepfer, R., Buttler, A., \& Vollenweider, P. (2017). Responses of antinomic foliar traits to experimental climate forcing in beech and spruce saplings. Environmental and Experimental Botany, 128-140. http://doi.org/http://dx.doi.org/10.1063/1.4923442

Schar, C., Vidale, P. L., Luthi, D., Frei, C., Haberli, C., Liniger, M. a, \& Appenzeller, C. (2004). The role of increasing temperature variability in European summer heatwaves. Nature, 427(6972), 332-336. http://doi.org/10.1038/nature02300

Sellin, A. (2001). Hydraulic and stomatal adjustment of Norway spruce tree to environmental stress. Tree Physiology, 21, 879-888.

Signarbieux, C., Toledano, E., Sanginés de Cárcer, P., Yongshuo, H. F., Schlaepfer, R., Buttler, A., \& Vitasse, Y. (2017). Asymmetric effects of cooler and warmer winters on beech phenology last beyond spring. Global Change Biology. http://doi.org/doi: 10.1111/gcb.13740

Smith, M. D. (2011). An ecological perspective on extreme climatic events: A synthetic definition and framework to guide future research. Journal of Ecology. http://doi.org/10.1111/j.13652745.2011.01798.x

Stephenson, D. B. (2008). Definition, diagnosis and origin of extreme weather and climate events. Climate Extremes and Society, 340. http://doi.org/10.1017/CBO9780511535840.003

Teskey, R., Wertin, T., Bauweraerts, I., Ameye, M., McGuire, M. A., \& Steppe, K. (2015). Responses of tree species to heat waves and extreme heat events. Plant, Cell and Environment, 38(9), 1699-1712. http://doi.org/10.1111/pce.12417

Vicca, S., Balzarolo, M., Filella, I., Granier, A., Herbst, M., Knohl, A., ... Peñuelas, J. (2016). Remotely-sensed detection of effects of extreme droughts on gross primary production. Scientific Reports, 6(March), 28269. http://doi.org/10.1038/srep28269

Vitasse, Y. (2009). Déterminismes environnemental et génétique de la phénologie des arbres de climat tempéré : suivi des dates de débourrement et de sénescence le long d'un gradient altitudinal et en tests de provenances. École doctorale Sciences et Environnements (Université Bordeaux). Retrieved from http://ori-oai.u-bordeaux1.fr/pdf/2009/VITASSE_YANN_2009.pdf

Way, D. A., \& Oren, R. (2010). Differential responses to changes in growth temperature between trees from different functional groups and biomes: a review and synthesis of data. Tree Physiology. http://doi.org/10.1093/treephys/tpq015

Zimmermann, N. E., Yoccoz, N. G., Edwards Jr., T. C., Meier, E. S., Thuiller, W., Guisan, A., ... Pearman, P. B. (2009). Climatic extremes improve predictions of spatial patterns of tree species. Proceedings of the National Academy of Sciences of the United States of America., 106(2),

This article is protected by copyright. All rights reserved. 
19723-19728. http://doi.org/10.1073/pnas.0901643106

Zweifel, R., Bohm, J. P., \& Hasler, R. (2002). Midday stomatal closure in Norway spruce - reactions in the upper and lower crown. Tree Physiology, 22(15-16), 1125-1136. http://doi.org/S

This article is protected by copyright. All rights reserved. 
Table 1: Interannual climatic variability along the elevational gradient during the study period. Mean annual air temperature and mean growing season length (GSL) was calculated for each species (F.s., beech; P.a., spruce), site, altitude and year. Average volumetric water content in the soil $\left(\mathrm{VWC}, \mathrm{m}^{3} / \mathrm{m}^{3}\right.$ ), measured at hour resolution by sensors 5TM (Decagon S.A) placed at $20 \mathrm{~cm}$ soil depth, during the period from May to July. For each length of growing season (GSL, days), we calculated the corresponding precipitation rate, number of hours with vapor-pressure deficit above $1.5 \mathrm{kPa}$ (VPD $>1.5$ ), number of hours of temperature below $5^{\circ} \mathrm{C}\left(\mathrm{T}<5^{\circ} \mathrm{C}\right)$, number of hours of temperature above $25^{\circ} \mathrm{C}\left(\mathrm{T}>25^{\circ} \mathrm{C}\right)$, number of hours of temperature below or equal to $0^{\circ} \mathrm{C}(\mathrm{T}$ $\left.\leq 0^{\circ} \mathrm{C}\right)$, and the number of events with more than 30 consecutive days without rainfall $(\mathrm{P} \geq 30)$.

\begin{tabular}{|c|c|c|c|c|c|c|c|c|c|c|c|c|c|c|c|c|c|c|c|c|}
\hline \multirow{3}{*}{$\begin{array}{l}\text { Altitude } \\
\text { (m) }\end{array}$} & \multirow{3}{*}{ Year } & \multirow{3}{*}{$\begin{array}{c}\text { Mean } \\
\text { annual } \\
\text { temp. } \\
\left({ }^{\circ} \mathrm{C}\right)\end{array}$} & \multirow{2}{*}{\multicolumn{2}{|c|}{ GSL (d) }} & \multirow{2}{*}{\multicolumn{2}{|c|}{$\begin{array}{c}\text { May-July } \\
\text { Soil VWC } \\
\left(\mathrm{m}^{3} / \mathrm{m}^{3}\right)\end{array}$}} & \multicolumn{14}{|c|}{ Growing season } \\
\hline & & & & & & & \multicolumn{2}{|c|}{$\begin{array}{c}\text { Mean temp. } \\
\left({ }^{\circ} \mathrm{C}\right)\end{array}$} & \multicolumn{2}{|c|}{$\begin{array}{l}\text { Precipitation } \\
\text { rate }(\mathrm{mm} / \mathrm{d})\end{array}$} & \multicolumn{2}{|c|}{$\begin{array}{c}\mathrm{VPD}>1.5 \\
\mathrm{kPa}(\mathrm{h})\end{array}$} & \multicolumn{2}{|c|}{$\begin{array}{c}\mathrm{T}<5^{\circ} \mathrm{C} \\
\text { (h) }\end{array}$} & \multicolumn{2}{|c|}{$\begin{array}{c}\mathrm{T}>25^{\circ} \mathrm{C} \\
\text { (h) }\end{array}$} & \multicolumn{2}{|c|}{$\begin{array}{c}\mathrm{T} \leq 0^{\circ} \mathrm{C} \\
\text { (h) }\end{array}$} & \multicolumn{2}{|c|}{$\begin{array}{c}\mathrm{P} \geq 30 \\
(\# \text { events) }\end{array}$} \\
\hline & & & F.s. & P.a. & F.s. & P.a. & F.s. & P.a. & F.s. & P.a. & F.s. & P.a. & F.s. & P.a. & F.s. & P.a. & F.s. & P.a. & F.s. & P.a. \\
\hline & 2013 & 5.0 & 98 & 93 & 0.38 & 0.31 & 12.7 & 12.5 & 4.4 & 4.6 & 28 & 16 & 204 & 204 & 23 & 17 & 3 & 3 & 0 & 0 \\
\hline \multirow[t]{2}{*}{1350} & 2014 & 5.9 & 133 & 125 & 0.40 & 0.32 & 11.3 & 11.5 & 4.2 & 4.3 & 41 & 41 & 189 & 148 & 6 & 6 & 0 & 0 & 0 & 0 \\
\hline & 2015 & 6.1 & 113 & 120 & 0.36 & 0.36 & 12.8 & 12.9 & 3.0 & 2.9 & 107 & 41 & 244 & 148 & 83 & 6 & 15 & 0 & 0 & 0 \\
\hline & 2013 & 5.2 & 142 & 141 & 0.44 & 0.39 & 10.9 & 11.0 & 4.7 & 4.5 & 48 & 48 & 209 & 196 & 86 & 86 & 2 & 2 & 0 & 0 \\
\hline \multirow[t]{2}{*}{1010} & 2014 & 7.7 & 158 & 159 & 0.54 & 0.22 & 12.8 & 12.8 & 4.8 & 4.8 & 33 & 33 & 95 & 95 & 34 & 34 & 0 & 0 & 0 & 0 \\
\hline & 2015 & 7.9 & 159 & 147 & 0.15 & 0.18 & 14.1 & 14.3 & 4.0 & 3.9 & 220 & 208 & 124 & 95 & 195 & 195 & 0 & 0 & 0 & 0 \\
\hline & 2013 & 9.8 & 152 & 148 & 0.20 & 0.20 & 17.6 & 17.7 & 1.9 & 2.0 & 160 & 160 & 35 & 35 & 186 & 186 & 0 & 0 & 1 & 1 \\
\hline \multirow[t]{2}{*}{570} & 2014 & 10.9 & 166 & 164 & 0.17 & 0.20 & 15.7 & 15.9 & 3.3 & 3.2 & 65 & 65 & 15 & 15 & 115 & 115 & 0 & 0 & 0 & 0 \\
\hline & 2015 & 10.6 & 174 & 166 & 0.10 & 0.17 & 17.2 & 17.5 & 3.8 & 3.2 & 444 & 441 & 10 & 6 & 447 & 447 & 0 & 0 & 0 & 0 \\
\hline Te & 2013 & 10.1 & 171 & 157 & 0.16 & 0.20 & 16.5 & 16.8 & 3.9 & 3.9 & 228 & 228 & 20 & 13 & 284 & 284 & 0 & 0 & 0 & 0 \\
\hline \multirow[t]{2}{*}{395} & 2014 & 11.4 & 182 & 169 & 0.14 & 0.16 & 16.1 & 16.5 & 3.1 & 3.2 & 92 & 92 & 23 & 1 & 77 & 77 & 0 & 0 & 0 & 0 \\
\hline & 2015 & 11.5 & 182 & 163 & 0.07 & 0.20 & 17.4 & 17.9 & 1.8 & 1.1 & 366 & 365 & 12 & 11 & 466 & 466 & 0 & 0 & 1 & 1 \\
\hline
\end{tabular}

This article is protected by copyright. All rights reserved. 
Table 2: Results from the GAMM model comparing means and extremes for beech and spruce. Biomass was used as the response variable explained by the climatic variables Rain (amount of precipitation per day during the growing season), AOVPD1.5 (number of hours during the growing season with VPD $>1.5 \mathrm{kPa}$ ), ABT5 (number of hours during the growing season with temperatures $<$ $5^{\circ} \mathrm{C}$ ), $\mathrm{T}_{\text {mean }}$ (mean temperature during the growing season) and Soil VWC (May-July). All explanatory variables were measured during the growing season. The model selection was based on the Bayesian information criterion (BIC), the Akaike information criterion (AIC) and log likelihood (logLik).

Beech

\begin{tabular}{|c|c|c|c|c|c|c|c|c|}
\hline Model & Response variable & $\begin{array}{c}\text { Explanatory } \\
\text { variable }\end{array}$ & Signif var. & R-sq(adj) & $\mathrm{df}$ & AIC & $\mathrm{BIC}$ & $\log \operatorname{Lik}$ \\
\hline \multirow[t]{3}{*}{1} & \multirow[t]{3}{*}{ sqrt (Biomass) } & Rain & n.s. & \multirow{3}{*}{0.15} & \multirow{3}{*}{10} & \multirow{3}{*}{140.9} & \multirow{3}{*}{152.7} & \multirow{3}{*}{-60.5} \\
\hline & & $\mathrm{T}_{\text {mean }}$ & $* * *$ & & & & & \\
\hline & & Soil VWC & n.s. & & & & & \\
\hline \multirow[t]{2}{*}{2} & \multirow[t]{2}{*}{ sqrt (Biomass) } & ABT5 & $* * *$ & \multirow{2}{*}{0.77} & \multirow{2}{*}{8} & \multirow{2}{*}{110.9} & \multirow{2}{*}{120.3} & \multirow{2}{*}{-47.5} \\
\hline & & AOVPD1.5 & $* * *$ & & & & & \\
\hline \multirow[t]{2}{*}{3} & \multirow[t]{2}{*}{ sqrt (Biomass) } & ABT5 & $* * *$ & \multirow[b]{2}{*}{0.50} & \multirow[b]{2}{*}{8} & \multirow[b]{2}{*}{124.8} & \multirow[b]{2}{*}{134.2} & \multirow[b]{2}{*}{-54.4} \\
\hline & & Soil VWC & $* *$ & & & & & \\
\hline
\end{tabular}

Spruce

\begin{tabular}{|c|c|c|c|c|c|c|c|c|}
\hline Model & Response variable & $\begin{array}{l}\text { Explanatory } \\
\text { variable }\end{array}$ & Signif var. & R-sq(adj) & df & AIC & $\mathrm{BIC}$ & $\log \mathrm{Lik}$ \\
\hline 4 & Biomass & Rain & n.s. & \multirow{3}{*}{0.34} & \multirow{3}{*}{10} & \multirow{3}{*}{267.6} & \multirow{3}{*}{278.1} & \multirow{3}{*}{-124.8} \\
\hline & & $\mathrm{T}_{\text {mean }}$ & $* *$ & & & & & \\
\hline & & Soil VWC & n.s. & & & & & \\
\hline 5 & Biomass & ABT5 & $* * *$ & \multirow{2}{*}{0.40} & \multirow{2}{*}{8} & \multirow{2}{*}{256.8} & \multirow{2}{*}{266.2} & \multirow{2}{*}{-120.4} \\
\hline & & AOVPD1.5 & $* * *$ & & & & & \\
\hline 6 & Biomass & $\begin{array}{l}\text { ABT5 } \\
\text { Soil VWC }\end{array}$ & $\begin{array}{l}\text { n.s. } \\
\text { n.s. }\end{array}$ & 0.04 & 8 & 271.1 & 277.4 & -126 \\
\hline
\end{tabular}

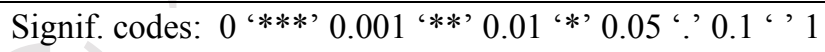

This article is protected by copyright. All rights reserved. 
Fig. 1. Time of budburst, budset and leaf senescence for the beech and spruce saplings along the elevational gradient in 2013, 2014 and 2015. The length of the growing season was defined as the time between the dates of budburst and senescence, represented by the numbers above the black lines (mean $\pm 1 \mathrm{SE}$ ). We pooled the treatments (irrigated and non-irrigated), because irrigation did not have a significant effect on the phenological dates. The number of replicates for each species and altitude were thus 20 in 2013 and 2014 and 10 in 2015.

Fig. 2. Relative increase in biomass after three growing seasons (2013-2015) at the control site (1350 $\mathrm{m}$ ) and the three recipient sites. (a) Relative biomass increase and (b) relative biomass increase standardized by the length of the growing season, which varied along the gradient and for each species. The data for the irrigated and non-irrigated treatments were pooled because irrigation did not have a significant effect $(P<0.05)$ on the increase in biomass during this period. Different letters represent significant differences within a species, uppercase for beech and lowercase for spruce, along the gradient identified by an ANOVA. The asterisks represent significant differences between the means $( \pm 1 \mathrm{SE})$ for each species at an altitude $(n=5)$ identified by a Tukey's post hoc test.

Fig. 3. The effect size ( $1350 \mathrm{~m}$ as the control site) of the biomass increase along the gradient and throughout the three years for both species and for the non-irrigated (a) and irrigated (b) treatments. The larger the absolute value, the higher the impact of the local conditions on the relative biomass increase (standardized by GSL). Different upper- and lowercase letters represent significant differences within a species and year, respectively, identified by Tukey's post hoc tests. Significant differences between the species at each altitude are indicated by asterisks above each graph. The biomass annual increase $\left(\Delta \% \mathrm{~d}^{-1}\right)$ was calculated for each sapling.

Fig. 4 Effect size (1350 $\mathrm{m}$ as the control) for biomass increase compared to the number of hours of VPD $>1.5 \mathrm{kPa}$ and the number of hours with $\mathrm{T}<5^{\circ} \mathrm{C}$ for both species and treatments. The larger the absolute value, the larger the impact of the extreme on the increase in biomass (standardized by GSL and initial biomass). Each dot is the mean at a site \pm 1 SE, with $n=10$ for 2013 and 2014 and $n=5$ for 2015 .

This article is protected by copyright. All rights reserved. 
Beech

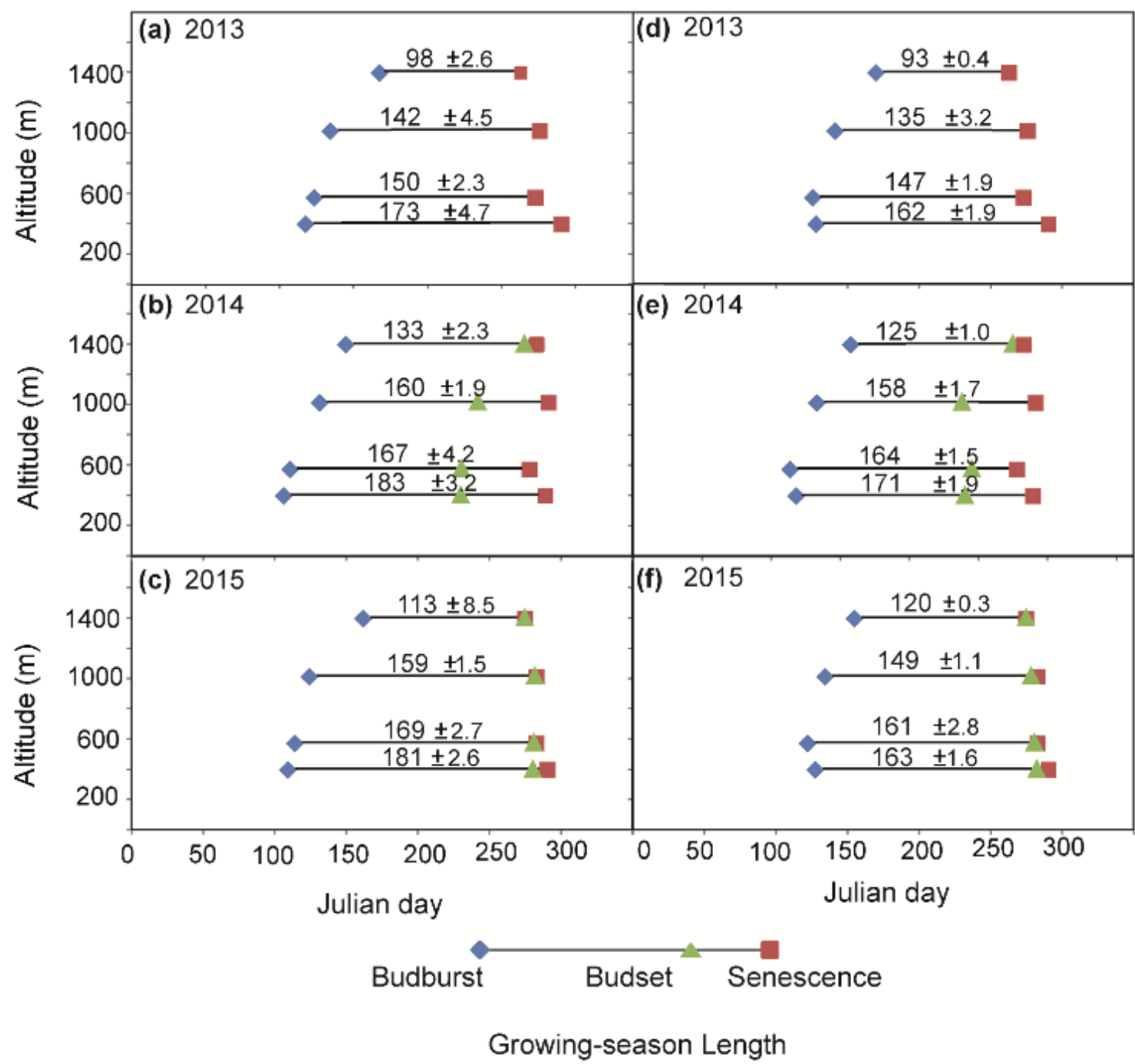

This article is protected by copyright. All rights reserved. 
(a)

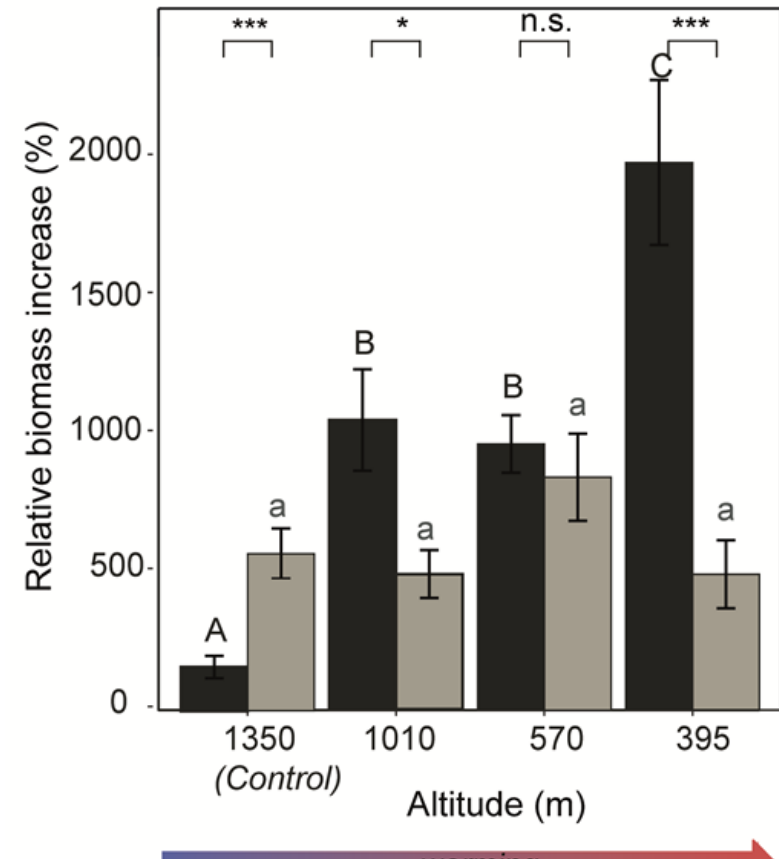

warming (b)

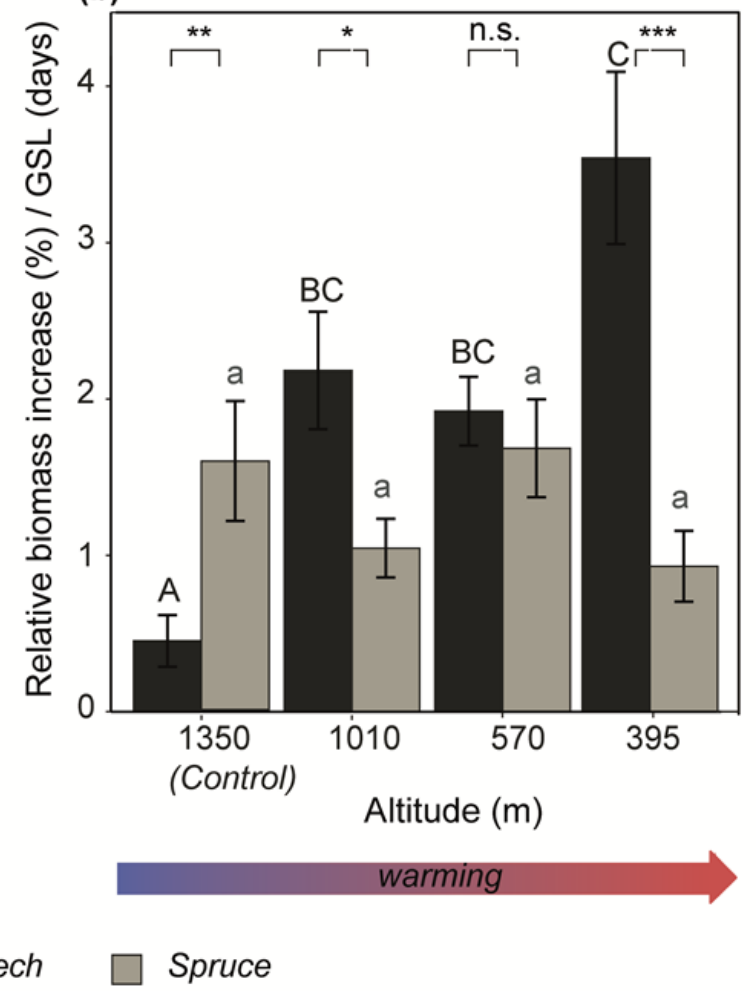

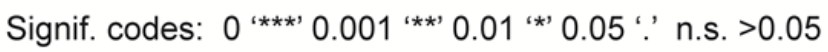


(a) Non-irrigated treatment

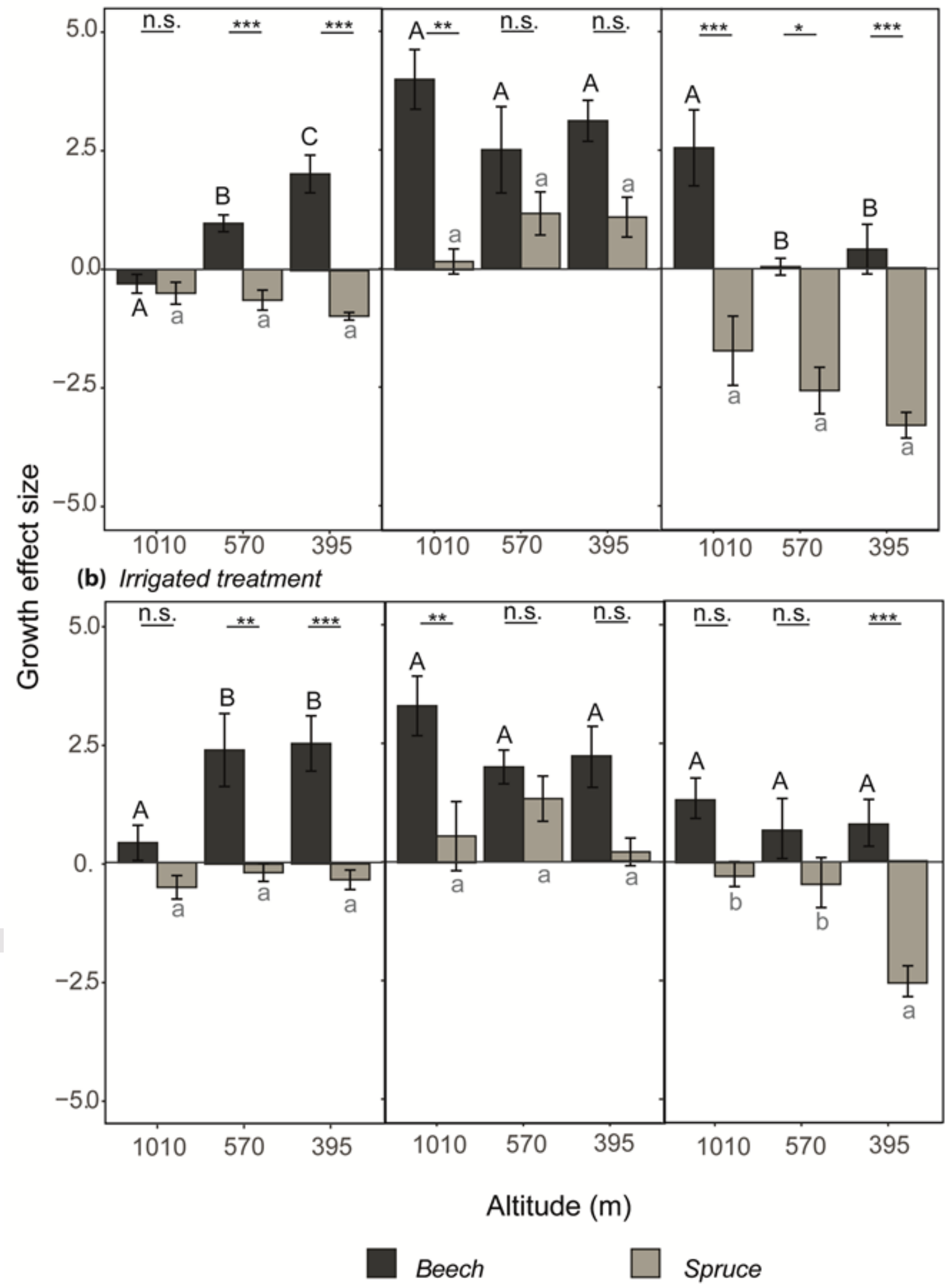

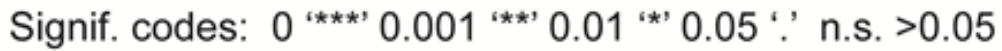



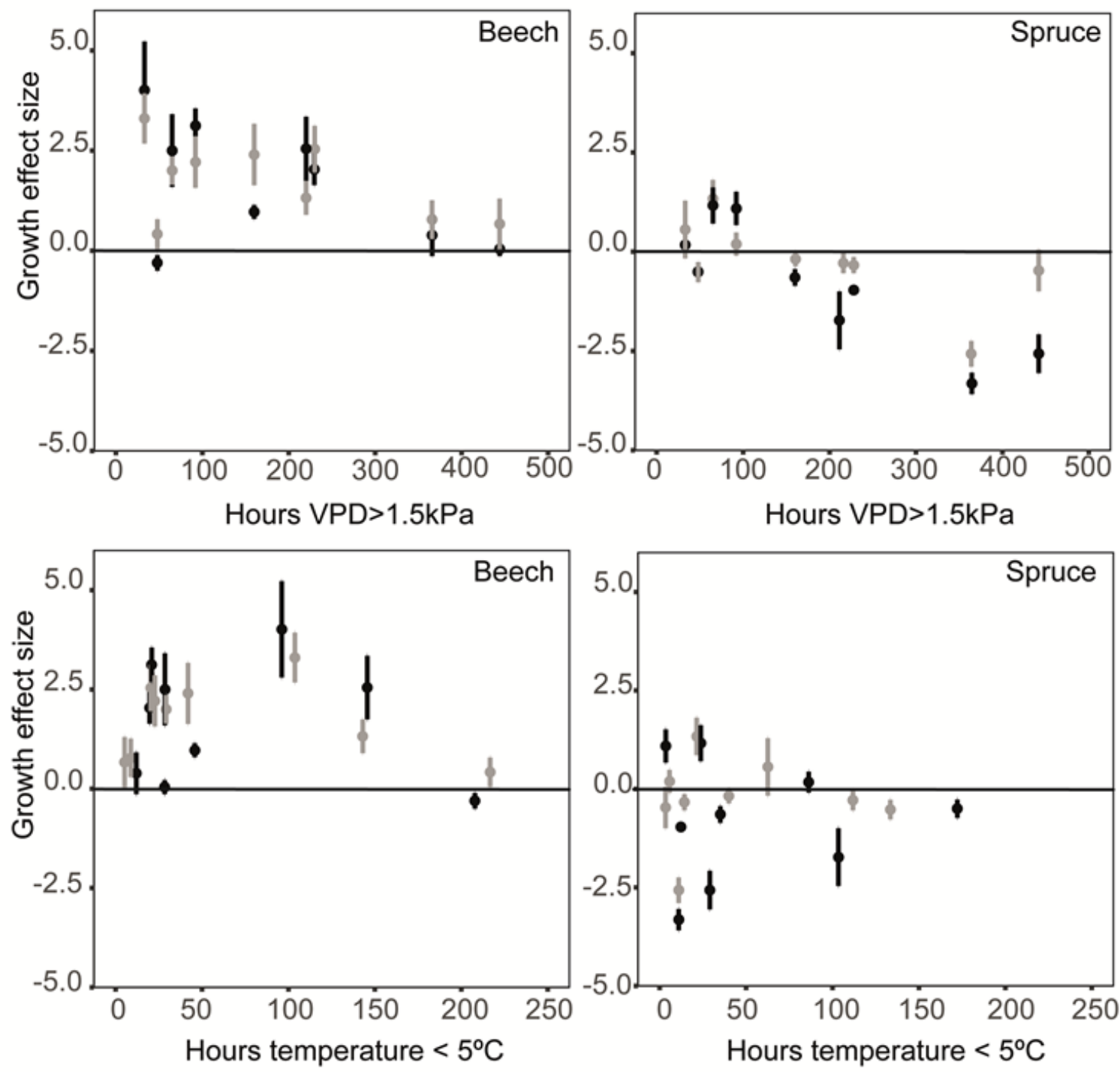

$\rightarrow$ Irrigated $\quad$ Non-irrigated 